\title{
Cross-Strait Relations 2008-2016: Progress, Problems, and Prospects
}

\author{
Jingdong Yuan
}

\begin{abstract}
Cross-Strait relations over the past eight years have witnessed noticeable improvement and contributed to peace and stability in the region. This article argues that Beijing and Taipei have yet to tackle more fundamental issues and move forward with political negotiations on the status of cross-Strait relations. The growing military imbalance over the past decade has eroded Taiwan's security and undermined its ability to negotiate with Beijing from a position of strength. With the DPP's Tsai winning the 2016 election and her refusal to formally embrace the "1992 Consensus," tensions could flare up again. Washington remains committed to Taiwan's security through defense cooperation and arms sales, but its willingness to do so will be tested by a rising China determined to resolve the issue on its own terms.
\end{abstract}

Keywords cross-Strait relations, military balance, 1992 Consensus, U.S.-China relations, U.S. arms sales, peace and security

\section{Introduction}

Cross-Strait relations have entered a new phase since the election of the Democratic Progressive Party (DPP) candidate Tsai Ing-wen as Taiwan's president in January 2016. While Tsai has been careful not to provoke the mainland by publicly vowing to maintain the status quo, Beijing remains suspicious and demands that she accept the "1992 Consensus" and the "One China" principle, where both sides acknowledge that Mainland China and Taiwan belong to one and the same China (Romberg 2016; Lam 2016). Whether and under what conditions relative peace and stability across the Strait can be maintained remains a critical issue. It is important, though, to look back over the past two decades of cross-Strait relations in the diplomatic, economic, and military spheres to determine the variables conducive to peace and circumstances that could stoke tension and conflict. 
The period of 2008-2016 was marked by noticeable improvement and relative stability in cross-Strait relations. Since the election of Ma Ying-jeou of the Kuomintang (KMT) as Taiwan's president in 2008, the two sides resumed semi-official relations and gradually moved toward official dialogue on the basis of the 1992 Consensus. A number of high-level official meetings were held. In November 2015, People's Republic of China (PRC) President Xi Jinping and Republic of China (ROC) President Ma Ying-jeou met in Singapore, a historic first meeting between the top leaders since 1946 when Mao and Chiang met in Chongqing. Twenty-three bilateral agreements were signed, some of which aim to facilitate and promote cross-Strait exchanges in trade, investment, tourism, education, and public health and have been implemented. Beijing and Taipei stuck to the tacitly agreed upon diplomatic ceasefire, and Taiwan was able to secure a place in the World Health Assembly (WHA) and the International Civil Aviation Organization (ICAO) as an observer. Most significant was the signing of the Economic Cooperation Framework Agreement (ECFA) in 2010, which provides free-trade area treatment to each other's commodity transactions, with Taiwan enjoying high growth rates in its exports to the mainland. Bilateral trade in 2014 reached $\$ 198$ billion, up from $\$ 8$ billion in 1991 (Albert 2016). The "three links" (post, transport, and trade) and direct flights across the Taiwan Strait further enhanced the flows of people and businesses, and have gradually contributed to better mutual understanding.

While improvement in cross-Strait relations has contributed to regional security and been welcomed in Washington as well as in Beijing and Taipei, fundamental issues, ranging from sovereignty to mutual recognition, and from Taiwan's international space and its status in any future cross-Strait political negotiation to China's ultimate goal of reunification, remain unresolved and could fray in the coming years. At the same time, the growing military imbalance, which is increasingly tilting in favor of the mainland, has policymakers in Taipei concerned over its ability to negotiate with Beijing from a position of strength. Following Ma's re-election victory over Tsai in the 2012 presidential elections and the 2012-13 leadership transition from Hu Jintao to Xi Jinping in China, these two leaders continued the expansion of bilateral ties, including exchanges between officials from both sides. At the same time, obstacles appeared blocking major breakthroughs in cross-Strait relations, including steps toward formal political negotiation. Meanwhile, Ma's deteriorating domestic approval ratings amid growing dissatisfaction with the KMT government resulted in major setbacks in introducing and implementing additional bilateral pacts aimed at further promoting trade in goods and services, and the ruling party's major defeat in Taiwan's local elections in late 2014 signaled the inevitable DPP victory in the 2016 presidential elections. China's newly minted fifth-generation leaders under $\mathrm{Xi}$, on the other hand, while continuing with the relatively moderate policy of winning the hearts and minds of the Taiwanese people, which was implemented 
during the $\mathrm{Hu}$ era, nonetheless have been under pressure to take strong positions on the Taiwan issue, especially with regard to the ultimate goal of national unification.

Indeed, despite the significant progress achieved over the past few years, major challenges lie ahead in the coming years now that the DPP has returned to power and controls both the legislative and executive branches of the Taiwanese government. The security environment across the Taiwan Strait has been relatively stable over the past eight years, but the sources of potential conflict and instability have remained potent (Crookes 2016). The United States has played a crucial role in helping maintain cross-Strait stability over the past three decades with its policy of strategic ambiguity and arms sales to Taiwan mandated by the 1979 Taiwan Relations Act (TRA). However, Washington is facing major challenges in balancing multiple and at times competing foreign policy objectives at a time of growing Chinese economic and military power and relative U.S. decline, not to mention the constraints imposed by out-of-control budget deficits. This has impeded the U.S. ability and willingness to provide defense assistance to Taiwan. At the same time, Taiwan's ability to defend itself is also facing significant challenges due to major military reforms, defense budget shortfalls, and the growing gap in military balances across the Strait.

\section{Cross-Strait Rapprochement}

Since the Ma administration came to power in May 2008, cross-Strait relations became relatively more stable and improved over time. During the presidential campaigns, Ma promised to reduce tension between Taiwan and the mainland and engage in cross-Strait relations based on the 1992 consensus-acceptance of the One China concept through each country's own respective interpretation. He also pledged that the "three no's"- no independence, no unification, and no use of force-would guide his mainland policy. Ma reiterated the "three no's" position in his inaugural speech of May 2008, which ushered in a new period of crossStrait reconciliation, expansion of ties, and improvement in relations (Cai 2011).

The rapprochement between the two sides is a sharp contrast with the period of 2000-2008 under the DPP Chen Shui-bian administration. Tension was running high and there were grave concerns that Chen's explicit push for de jure independence could provoke the mainland into using force, which in turn could drag the United States to a major military confrontation with China (Bush 2005; Rigger 2013). Ma's conciliatory posture was reciprocated by the $\mathrm{Hu}$ administration, which essentially shifted the near-term focus of its Taiwan policy from pursuing unification goals to preventing the island from moving toward independence or separation (Saunders and Kastner 2009, 88). The March 2005 Anti-Secession Law, passed during a period of heightened tension in cross-Strait 
relations, lays down the legal marker on what Beijing considers-and declaresthe red-line where all options are open to deter any independence tendencies (You 2006). But the law also emphasizes and advocates the promotion of contacts between the two sides and, with Ma's victory in the 2008 presidential election, Beijing was able to put into practice a new Taiwan policy which emphasizes winning the hearts and minds of the Taiwanese people and worked toward the long-term prospect of unification. For that purpose, the Hu administration had advocated increasing communication and dialogue on economic, political, diplomatic, and security issues, with a focus on boosting peaceful development across the Taiwan Strait (Xin 2010).

Ma's mainland policy and Beijing's near-term focus resulted in the restoration and regularization of high-level semi-official dialogues between Taiwan's Straits Exchange Foundation (SEF) and the mainland's Association for Relations Across the Taiwan Strait (ARATS), and eventually official direct interactions between Beijing's Taiwan Affairs Office (TAO) and Taipei's Mainland Affairs Council (MAC). These exchanges and negotiations between the two sides facilitated the expansion of trade, investment, and greater interaction between people across the Strait. Direct flights now number in the hundreds per week. Over one million Taiwanese live permanently in mainland China while 4.3 million mainland tourists visited Taiwan in 2015 (Chiao 2016). Trade and investment have grown rapidly, with Taiwan enjoying a sizeable surplus. China has become Taiwan's largest trading partner and the number one destination for its exports. Seventy thousand Taiwanese companies run businesses in China, with over $\$ 137$ billion in investment approved by the Taiwanese authorities between 1991 and 2013, accounting for 60 percent of Taiwan's foreign investment (Kan and Morrison 2014; Huang 2016; Hickey 2015, 374). Indeed, Taiwan's growing exports to the mainland over the last few years have helped the island weather the global economic downturn in the wake of the 2008 global financial crisis. Meanwhile, the signing of the ECFA has also opened up the possibility for Taipei to conclude similar free-trade type arrangements with other countries; for instance, Taiwan has concluded FTAs with both Singapore and New Zealand (Meltzer 2014).

Ma's strategy of assuring the mainland, i.e., that under his administration the status quo (i.e., no independence and no unification) would be maintained, coupled with efforts to expand bilateral economic ties and institutionalize dialogues, eased cross-Strait tensions and helped develop and promote common interests, enhance mutual trust, and hence the incentives for keeping the peace (Zhang 2011; Bush 2013). In essence, Ma believed that "Taiwan could better assure its prosperity, dignity, and security by engaging and reassuring China rather than provoking it" (Bush 2011, 275). Some analysts argued that based on the progress achieved and building upon the moment, it was possible and perhaps desirable for both sides to negotiate a peace agreement. For Taiwan, this could lock in a mainland commitment not to use force; for Beijing, such an 
agreement could constrain future non-KMT governments from activities toward independence. In fact, cross-Strait rapprochement also served the mainland's interest in gradually expanding its influence over the island as the latter's dependence on the mainland grew. And it allowed the People's Liberation Army (PLA) to continue its modernization programs without being prematurely forced into a military showdown with Taiwan and, more critically, the United States. At the same time, the relatively stable environment provided the two sides with the opportunity to seriously consider cross-Strait confidence building measures (You 2013; Saunders and Kastner 2009, 91; Glaser and Glosserman 2008). Ma's election victory over Tsai in 2012 was thought to suggest that Taiwan's voters preferred continuity over uncertain policy change under a DPP government (Bush 2013, 123).

If one accepts the argument that close economic interdependence offers better prospects for peace, then one would be encouraged by the developments over the last few years. Obviously, any conflict in this situation would incur high costs for both sides, but the reduction of tension and the apparent relative stability do not mean that threats and insecurity no longer exist. In fact, despite the progress made in growing bilateral trade, investment, cultural exchanges, education, and direct bilateral official dialogues, the fundamental issues that affect long-term cross-Strait peace and stability, and in particular Taiwan's security, have remained unresolved. Ma was restrained domestically from making major political breakthroughs despite, and perhaps because of, his 2011 statement that he might consider a peace accord with Beijing; for instance, the DPP's Tsai charged that Ma could put Taiwan's future at risk by sacrificing its sovereignty (ibid., 122). Beijing's ultimate goal of unification and its steadfast adherence to the One China principle continued to guide its policy toward Taiwan, including the use of diplomatic, military, as well as economic means (Moore 2016; Bush 2011, 277). Indeed, as the 2015 Taiwan defense white paper points out, "crossStrait relations have eased as a result of increasing economic, cultural, and educational exchange. However, the PRC is still preparing various strategic moves against Taiwan" (MND/ROC 2015, 51). Not surprisingly, the DPP often warned that the KMT government could put Taiwan's long-term security and independence at jeopardy by moving too close and too fast in expanding ties with the mainland. Tsai accused Ma of pursuing a dangerous policy of "gambling Taiwan's sovereignty in exchange for short-term economic benefits from China" (Glaser 2012; Lee 2011). However, just as political tension did not prevent growth in economic interactions across the Strait even during the 2000-2008 Chen Shuibian presidency, it would be equally simplistic to argue that growing economic contacts between the two sides, in particular Taiwanese businesses' increasing dependence on the mainland, could inevitably give Beijing the political upperhand (Kastner 2009; Keng and Schubert 2010).

What then can explain the overall cross-Strait rapprochement but lack of a 
breakthrough during Ma's tenure, and should it be expected that in the coming years Tsai's resistance to Beijing's One China principle will result in deterioration of ties? This must be placed within both the domestic contexts in China and Taiwan, and the broader environment of the triangular relationships between Beijing, Taipei, and Washington. First and foremost, it should be emphasized that cross-Strait rapprochement was deemed imperative from the perspectives of both Beijing and Taipei after the tumultuous DDP government under Chen Shuibian. After Chen narrowly won his second term in 2004, Beijing recalibrated its Taiwan policy from one of threat and hostility to a more balanced approach of deterrence against Taiwan independence (through the 2005 Anti-Secession Law) combined with reaching out to the opposition KMT and building a coalition with groups across the Strait-business community, politicians, intellectuals-that opposed de jure independence. Second, Ma reversed Chen's policy and placed greater emphasis on economic recovery, which was to be achieved through rapprochement and expansion of economic ties with the mainland. Ma's "three no's" position was tacitly accepted by Beijing and the two sides also agreed to a diplomatic truce that largely ensured stability and the maintenance of the status quo (Wang 2016, 578-580; Albert 2016).

Third, Sino-U.S. relations were relatively stable during Ma's first term in office (2008-2012). The 2007-2008 global financial crisis and U.S. wars in Afghanistan and Iraq greatly weakened American power and the Obama administration began in 2009 preoccupied with addressing domestic economic woes and managing global economic challenges. Obama's more conciliatory and cooperative approaches to diplomacy and China's growing power provided the opportunity for Beijing and Washington to work together on critical global and regional issues from climate change to the North Korean nuclear issue. This overall environment allowed Taipei to improve relations with both Beijing and Washington (Blanchard and Shen 2015; Hickey 2015; Wang 2013). And finally, cross-Strait rapprochement has generally enjoyed domestic support in both China and Taiwan. Despite Beijing's leadership transition in 2012-13, China's Taiwan policy remained by and large intact. The Chinese leadership's policy of patience and engagement continued, even when major backlashes, such as the Sun Flower movement against the Cross-Strait Service Trade Agreement (CSTA) and nine-inone local elections, caused setbacks for the KMT in 2014 and called into question the efficacy of the KMT government. For the time being at least, China appears determined to stay the course and continue to pursue peaceful development of cross-Strait relations (Lin 2016). Likewise, cross-Strait rapprochement has also had support from a solid majority (55.6 percent) of Taiwanese. A larger majority of voters (68.2 percent) also endorsed Ma's position that there was no need to declare independence as Taiwan is already a de facto independent state (Hickey and Niou 2016, 59). Even Tsai, during her presidential campaign in 2015, tried to assure Washington and Taiwan's electorate that she would maintain the status quo 
if elected.

However, despite improvement in cross-Strait relations during Ma's time in office, no major breakthrough was accomplished. While limited direct official exchanges between the two sides' ministries in charge of cross-Strait relations took place and Xi and Ma met in Singapore in November 2015, Beijing and Taipei were not able to move beyond the phase of "low hanging fruit" to the more sensitive and hence more difficult task of engaging in political negotiation. Their interpretations of the status quo and stability also differ. For Beijing, the status quo means that Taipei would not seek de jure independence and adhere to the 1992 Consensus, but this is the minimum Beijing expects and the mainland does not envision this as a permanent solution. On the contrary, the Chinese leadership and Chinese people see the ultimate goal of reunification with the island as the final chapter of a rising power cleansing itself of past humiliation (Bush 2016). On the other hand, Ma remained committed to the "three no's" position as he had little room or political capital to bend under pressure from the mainland for a number of reasons. First, despite whatever economic gains Taiwan was able to procure through expanding trade and investment with China, its economic recovery was slow. There was growing concern regarding Taiwan's over-dependence on China, which resulted in a violent protest against the CSTA and the rise of the Sun Flower Movement (Hsueh 2014). Second, expansion of interactions across the Strait has not narrowed the perceptions of people toward each other; if anything, the Taiwanese identity has developed further. A 2015 survey conducted by National Chengchi University shows that a sizeable majority (60.6 percent) of respondents polled consider themselves to be Taiwanese and those who self-identified as Chinese was at a historic low of merely 3.5 percent. This is hardly a conducive environment for political negotiation even though the two sides remained committed to the 1992 Consensus (Tseng and Chen 2015; Babones 2016).

Third, while Ma's policy and Beijing's tactic adjustments over the past decade have fostered an environment of relative peace and stability, the fundamental sources of conflict and instability have never been fully addressed. China has consistently repeated its sovereignty claim over Taiwan, with the use of force always an unequivocal and ultimate means at the ready to deter and compel the latter to its terms of an eventual political settlement. Indeed, beyond economic, societal, and cultural exchanges, bilateral contacts in the security (except in nontraditional security areas of anti-piracy, health, and humanitarian assistance) sphere, let alone military exchanges, remain almost non-existent. There have been scholarly and, at times, limited official rhetoric about discussing, negotiating, and establishing cross-Strait confidence building measures (CBMs), but nothing of substance has ever taken off (Kan 2013). At the same time, reassurance strategies aimed at convincing the other side of one's benign intentions have fallen short of building trust and removing threats. Beijing is wary and unwilling to allow Taipei 
greater international space for fear of being seen as acquiescing to Taiwan's status as a state; Taipei views Beijing's obstructing of its participation in international organizations as proof of PRC attempts to marginalize Taiwan in the international community. The situation will only become more difficult for Tsai's government (Liao 2014, 2012; deLisle 2016). The PLA, normally a more hawkish element in Chinese national security policy, remains a strong voice in Beijing's Taiwan policymaking and Chinese military buildup continues, adding further weight to the mainland's side of the cross-Strait military balance (B. Glaser 2015).

Indeed, cross-Strait peace and stability depends on both military balance and the (in)ability to attack/defend the island. In contrast to China's rapid growth and military modernization over the past two decades, Taiwan's defense has not kept up and in many aspects actually stalled, hindered by its inability to maintain the pledged level of defense spending ( 3 percent of GDP; actual spending has hovered around 2.1 percent of GDP in recent years), costs of moving toward a professional military, the non-combatant tasks the ROC armed forces have had to undertake in recent years, and the outlays needed for major weapon procurement programs (Tan 2014). All of these have imposed a significant financial burden and the lack of sufficient resources has limited what could be accomplished with regard to the stated defense modernization plans laid out in the first-ever Quadrennial Defense Review (QDR) (Mei 2011; Huang 2011). The defense budget shortfalls stand in contrast to the mainland's growing defense spending and military buildup which has resulted in advanced military capabilities that not only pose a more serious threat to Taiwan and have important implications for Taiwan's national security, but constrain the ability of the United States to intervene in any potential conflict. Some analysts have already pointed to Taiwan's diminishing freedom of action that overtime could seriously undermine its sovereignty and autonomy, paving the way for the mainland to achieve its ultimate goal-unification on its own terms (USCC 2015, 491-532; Shlapak et al. 2009).

Critics have charged that Ma's strategy of reassurance failed to stop Beijing's squeezing of Taiwan's international space and to reduce its steady military buildup against the island, in particular the deployment of over 1,000 short-range ballistic missiles across the Strait. It is true that the mainland had refrained during Ma's tenure from diplomatic offensives aimed at luring away countries that still maintain official ties with Taipei, and did not explicitly exploit Taiwan's growing economic dependence to exert pressure on Taipei to engage in more substantive political negotiations. However, according to the latest Pentagon report on China's military power, "there have been no signs that China's military posture opposite Taiwan has changed significantly" (DOD 2016, 87). In fact, neither side has given up its fundamental stance on the sovereignty question and both continue to engage in military preparations-with the mainland aiming to deter Taiwan from independence and coercing the island into eventual unification on Beijing's terms, and Taiwan striving to raise the cost of China's use of force through 
defense and dependence on security commitments from the United States. The only difference is that Taiwan's defensive advantages have declined despite the efforts by the Ma administration. Overtime, though, this is a game that Taiwan will lose given that the changing military balance is increasingly tilting in China's favor and the frustrated Ma administration is unable to secure the weapons systems it needs from the United States, including the 66 F-16 C/D fighter aircraft it deemed crucial for the island's defense (Minnick 2011).

Current President Tsai's ambivalence in her approach to cross-Strait relations could lead to the reversal of the stability of the previous past eight years and growing tensions in the years to come. The challenges for Tsai are to introduce and implement a mainland China policy that would not be viewed by the DPP base and the general public in Taiwan as a betrayal of the island's interests while at the same time is not seen by Beijing as an attempt, however concealed or presented, toward Taiwan's independence. For instance, Tsai has so far refused to use or embrace the term "1992 Consensus." However, she has characterized it as a historical fact in an effort to provide some reassurances to the PRC. Mainland China has so far maintained a "wait and see" stance while rejecting Tsai's rhetoric as failing to pass the test, i.e., the acknowledgement of the core of the 1992 Consensus that both sides of the Taiwan Strait belong to one China. Beijing remains deeply suspicious of Tsai, not the least because of her role in both the Lee Teng-hui and Chen Shui-bian administrations in advocating the proindependence posture (B. Glaser 2016). There is growing concern that Beijing's patience is wearing thin and that the Xi leadership may well have set a timetable for unification and even use force to compel Taipei to accept its terms. Already, China has suspended all official exchanges with Taiwan and more punitive measures can be anticipated. This could unravel stability achieved over the past eight years (Zhao 2016; Glaser and Vitello 2015).

\section{Changing Military Balance}

China has been modernizing its military since the end of the Cold War. Key features of its modernization efforts include the restructuring of the PLA combat forces in the areas of doctrinal development, training, and recruitment; procurement of major conventional weapons systems, mainly from the Russian Federation as well as enhancement of indigenous defense industrial capabilities; nuclear and missile modernization; and significant increases in defense spending. The Chinese military is fully appreciative of the technological changes that are revolutionizing modern warfare. On the one hand, new military technology and equipment have changed the way warfare is conducted. On the other hand, requirements demanded by the military in terms of how war should be executed has provided the impetus for technological developments and breakthroughs. 
Under such circumstances, how to deal with the technological gap that exists between armed forces in developed countries and the PLA has become an important issue. The PLA lags behind major military powers in several areas, such as the abilities to collect, process, and transmit information between the central command and the theatre of war; mobility and quick-reaction capacity; and precise, long-range firepower. Closing this gap requires not only a fundamental change in military doctrine but also involves major procurement, force restructuring, recruitment and retention of military talent, and steady increases of resources to support a modernizing military that is becoming more expensive. Notwithstanding the significant increases in defense spending over the past two decades, there is still much to be desired as far as all-round defense modernization is concerned (Shambaugh 2003; Cliff 2015).

With double-digit defense spending increases over the past two decades, the PLA has been engaged in major upgrades and procurement of weapons systems, principally with the help of Russia, but indigenous defense industries have also been playing an increasing role. According to the arms-transfer database compiled by the Stockholm International Peace Research Institute, China spent over $\$ 20$ billion between 1992 and 2005 in purchasing Russian weapons, about 89 percent of its total foreign arms imports during the same period (SIPRI 2016). The acquisition of Russian weapons systems has enhanced the PLA's power projection capabilities. For instance, the Su-27 is an air superiority fighter designed for air-to-air combat and equipped with Russia's most advanced avionics. It has a range of $4,000 \mathrm{~km}$ in internal fuel tanks and a combat radius of approximately $1,500 \mathrm{~km}$. With aerial refueling technology, this would enable the PLA Air Force (PLAAF) to extend air control over the Spratly island group. The Kilo-class submarine has a range of $9,650 \mathrm{~km}$ and the ability to remain at sea for up to forty-five days. China already purchased twelve and may buy up to twentytwo diesel-powered submarines (SSKs) from Russia. The Sovremenny-class destroyers are equipped with SS-N-22/Sunburn anti-ship cruise missiles designed to defeat the U.S. Navy's Aegis air-defense system, therefore enhancing their antiaircraft carrier capabilities (Starr 1995, 3; Kan, Bolkcom, and O'Rourke 2000; Bräuner, Bromley, and Duchâtel 2015).

The Chinese military has devoted a growing amount of resources to developing capabilities to resolve the Taiwan issue. Three areas have received particular attention. China has increased the number of deployed short-range ballistic missiles (SRBM)-DF-9 and DF-11-from a few dozen in the mid1990 s to the current number of over 1,200 (USCC 2015, 506). The PLAAF now possesses over 600 modern combat aircraft, including Russian Su-27 and Su-30 fighter aircraft, the indigenous J-10 and J-11, and has recently tested the J-20, its version of a stealth fighter aircraft. It has been reported that Russia has agreed to sell twenty-four Su-35 multi-role combat aircraft to China (IISS 2016, 224). These new developments have eroded Taiwan's air superiority. The PLA Navy (PLAN) is 
acquiring major surface battleships and submarines to establish sea dominance. These include the 052D destroyer, 054A frigate, and 056 corvette classes. China's first aircraft carrier, the Liaoning, has conducted several sea trials and it has been reported that two indigenously manufactured carriers are currently under construction. The Jin-class ballistic missile submarines appear to be in operation while improvement of the Type-093 nuclear-powered attack submarines has reportedly been completed. And increasingly the PLA is expanding and strengthening its amphibious capabilities, with joint all-service military training and exercises increasingly focusing on amphibious attacks, and the building of amphibious transport docks as well as the acquisition of utility landing craft (DOD 2016, 92). These developments are a sharp contrast to earlier assessments of China's military capabilities in the late 2000s when President Barack Obama assumed office. For instance, the DOD reports published a few years ago, while clearly recognizing the progress in Chinese defense modernization, also noted the limitation of the Chinese military in equipment, training, and operations. They suggested that the PLAAF only had a limited number of modern, fourth generation fighters and the PLAN did not possess sufficient sea lift capabilities for major amphibious operations. There was sufficient confidence at the time that the cross-Strait military balance had yet to definitively shift to Beijing's favor, failing to recognize that with continuing force modernization China's growing military power would eventually erode the qualitative edges Taiwan might still enjoy (DOD 2010).

The PLA has introduced and deployed a growing number of land-based anti-ship ballistic missiles, land-attack cruise missiles, and air-launched antiship cruise missiles, such as the DF-21D, DH-10, and YJ-63 in support of the concept of "anti-access/area-denial" (A2/AD) - the idea of disrupting, weakening, and denying the U.S. ability to deploy troops to overseas theaters of operations given the American military's dependence on such assets as forward basing, depots, information networks, sea lanes of communication (SLOC), among others, to ensure operational effectiveness and successes (Erickson and Yuan 2011; Krepinevich, Watts, and Work 2003). A RAND study defines an antiaccess measure as "any action by an opponent that has the effect of slowing the deployment of friendly forces into a theater, preventing them from operating from certain locations within that theater, or causing them to operate from distances farther from the locus of conflict than they would normally prefer" (Cliff et al. 2007, 11). The PLA's Strategic Rocket Force is also upgrading its full-range ballistic missile types and fielding new systems, as recently displayed during the September 2015 Military Parade, including the DF-16, DF-26, and DF-5B (IISS 2016, 222).

The changing military balance raises serious questions for both Taiwan's security and potential U.S. military intervention in a cross-Strait crisis and, as a consequence, the PLA's ability to confront a much stronger U.S. military to protect 
China's core interest, i.e., sovereignty over Taiwan. The RAND study on Chinese anti-access strategies has identified a number of ways and a multitude of possible targets that the Chinese military may contemplate employing and attacking to ensure that it can prevail over-or at least avoid defeat by-the United States in that theater of military operations. These include $C^{4}$ ISR systems, logistics and transportation, air bases, sea lanes and ports, aircraft carriers, among others. The first and the last elements are of particular importance as the U.S. military is highly dependent on both to operate effectively (Cliff et al. 2007, 51-79). A recent study suggests that over the twenty year period since the 1995-96 Taiwan Strait crisis, many of the advantages that the U.S. military enjoyed at the time have been eroded by gradual Chinese military modernization which is narrowing, if not closing, the gap. As a result, "the defense of Taiwan would place U.S. forces at an acute operational disadvantage, given the immediate proximity to the mainland and the optimization of Chinese forces for the tasks at hand" (Heginbotham et al. 2015, 332).

Western analysts of Chinese military options vis-à-vis Taiwan generally include two schools: one holding that the Chinese military would undertake a measured approach, involving a deliberate build-up of overwhelming military force for the purpose of coercing Taiwan to submit to China's pressure to standdown in a crisis; the other school of analytical opinion avers that China would employ surprise to achieve rapid success against Taiwan before the United States had sufficient time to intervene. Chinese military strategists have devoted considerable space to the importance of seizing the initiative from the very beginning of a military campaign. RAND Corporation analysts, in assessing China's emerging anti-access strategies, quote one Chinese military analyst as saying that "in a high-tech local war, a belligerent which adopts a passive defensive strategy and launches no offensive against the enemy is bound to fold its hands and await destruction" (Mulvenon and Finkelstein 2005).

Clearly, Chinese military modernization over the past two decades is steadily changing the military balance across the Taiwan Strait in Beijing's favor. Granted, not all of the weapons procured and deployed have been driven by the Taiwan factor; China's growing economic interactions with the outside world have expanded and exposed its interests that require protection and hence power projection (Glosny 2011). However, the fact that the mainland now has an ever growing inventory that it can draw upon in a future Taiwan scenario makes it imperative that Taiwan's defense policy, including force structure and arms procurement, must be informed by the need to protect its political autonomy, resist Chinese coercion, and defend against Chinese assault (MND/ROC 2015).

Over the past decade, as Chinese military modernization continued, so too has Taiwan's arms purchases from the United States. Between 2005 and 2015, Taipei has sought to purchase over $\$ 22.7$ billion in defense articles and services (USCC 2015, 518; Kan 2014). In October 2008, soon after Ma assumed office, 
the Bush administration announced the provision of a long-delayed $\$ 6.5$ billion package of weapons to Taiwan. Although the announcement prompted stormy protests from Beijing, it was well received in Taipei. The Obama administration's January 2010 arms sales package of $\$ 6.4$ billion contained some of the items already approved by the Bush administration; another purchase of $\$ 5.9$ billion in arms was announced in September 2011; and more recently, in December 2015 , a $\$ 1.83$ billion arms sale, including two warships, was concluded. Beijing responded by threatening to impose sanctions on the involved U.S. companies in addition to cancelling bilateral high-level exchanges, including those between the U.S. military and the PLA (Kok and Firestein 2013; Forsythe 2015).

Taipei's arms acquisition efforts are aimed at maintaining military balance across the Strait, thus ensuring a level of security and stability necessary for Taiwan's continued social and economic wellbeing. While not completely ruling out negotiation with the mainland, Taipei has rejected any pre-conditions for talks. Adequate defensive capabilities are the only guarantee to ensure an outcome not based solely on Beijing's terms. Taiwan's current inventory of 150 F-16s, sixty Mirage 2000-5s, and some 130 Ching-kuo Indigenous Defense Fighters (IDF) had enabled it to maintain air superiority over the Taiwan Strait in the past. However, it will increasingly lose that edge unless and until its request for a new fleet of combat aircraft is met or, at the very minimum, significant upgrades to its current fighter aircraft can be provided. The acquisitions of Knox-class frigates, Kidd-class destroyers, anti-submarine S-2T, E-2T Hawkeye airborne earlywarning aircraft, long-range early-warning radars, attack helicopters, Patriotderived Modified Air Defense Systems, Hawk and Chaparral ground-based air defense systems, PC-3 maritime patrol aircraft, among others, have been largely driven by the objectives of enabling Taiwan to maintain relative (albeit declining) aerial superiority, anti-air warfare, anti-submarine warfare (ASW), and antisurface warfare capabilities, and to counter emerging Chinese threats in these areas (Kan 2014; USCC 2015). Given that China has succeeded over the past two decades in dissuading previous and potential suppliers from selling arms to Taiwan, the role of the United States has become ever more critical. However, the uneven and sometimes precarious nature of the U.S. arms sales policy has raised larger questions about the interpretation and implementation of the TRA since its enactment in 1979 (Goldstein and Schriver 2001).

Overall, U.S. administrations since Reagan have largely been cautious in either delaying or altogether not selling certain types of weapon systems that Taipei would like to procure, such as the Aegis missile defense systems, or F-16 C/D fighter aircraft and, until late 2008, Patriot Advanced Capability-3 (PAC-3) missile defense batteries, given that the sensitive nature could elicit a strong PRC response (Lee 2000). However, the issue remains one of glass half-full or halfempty depending on where one sits. Certainly from Beijing's perspective, over the last three decades since the August 17, 1982 joint communiqué was issued, 
the United States has provided Taiwan with a full spectrum of military equipment in blatant violation of China's sovereignty. The U.S. Department of Defense also runs exchange programs with Taiwan on $\mathrm{C}^{4} \mathrm{I}$, air defense, and ASW. Taiwanese military officers attend U.S. military academies and defense cooperation meetings (Huang 2010; Kan and Morrison 2014).

In October 2008, as the Bush administration entered its final months in office, it notified Congress of plans to sell Taiwan more than $\$ 6.4$ billion in military equipment. The announced sales included PAC-3 missiles, Apache Longbow attack helicopters, Javelin guided anti-tank missiles, Harpoon missiles, spare parts for F-16s, and upgrades for E-2T Hawkeye 2000 earlywarning aircraft (McNeil 2008). In January 2010, after some delay when the Obama administration sought to consolidate U.S.-China relations with a view to soliciting Beijing's cooperation on issues such as Iranian and North Korean nuclear programs, Obama's November 2009 visit to China, and the December 2009 Copenhagen UN climate conference, a package of arms worth $\$ 6.4$ billion was submitted to Congress. The package included 114 PAC-3 missile defense missiles, sixty UH-60M Black Hawk utility helicopters, twelve Harpoon Block II anti-ship telemetry (training) missiles, sixty Multifunctional Information Distribution Systems (MIDS), and two refurbished Osprey-class Mine Hunting Ships (Minnick 2010).

U.S.-Taiwan defense ties are not confined to U.S. arms sales only. Over the years, the United States and Taiwan have developed close defense cooperation that goes beyond just arms sales. This includes regular defense consultation, such as the so-called "Monterey Talks" which were first held in Monterey, California in 1997, training of Taiwanese military officers in U.S. military institutions, participation of U.S. military personnel in Taiwanese military exercises such as the Hankuang, and training related to the transfer of procured defense equipment. What are considered "software" issues are meant to enhance Taiwan's ability to better integrate and absorb U.S. defense systems. In addition, more frequent interactions between Taiwan and the United States at the functional level enable Washington to better understand Taipei's defense planning and procurement processes so that effective coordination during crises can be facilitated. In 2002, the Bush administration asked Congress to pass legislation to allow active-duty U.S. military personnel to be assigned to Taiwan. Subsequently, in August 2005, a U.S. Army Colonel was stationed in Taipei although he would be wearing civilian clothes (Chase 2005). Over 3,000 U.S. Department of Defense personnel visited Taiwan in 2014 (USCC 2015, 519).

However, enhanced military-to-military contacts and the need to upgrade Taiwan's weapons systems have also imposed significant resource and political burdens on Taipei. In addition, there have been differences between the types of weapons systems Taipei seeks to acquire and what Washington is willing to provide for various reasons. For instance, Taiwan has made requests for the 
Arleigh Burke-class, Aegis-equipped destroyer but the United States has yet to respond. Four Kidd-class destroyers were approved for Taiwan's purchase and have been delivered. The deal was quite controversial and it was not until after heated debates in the Taiwanese legislature that the special funding was finally secured in 2003. Taiwan's requests for 66 F-16 C/D fighter aircraft have also not been met by U.S. administrations, even though they are improved versions of the F-16 A/B which Taiwan already possesses. At the same time, the diesel-electric submarines that the Bush administration announced would be sold to Taiwan in April 2001 have been in limbo for past ten years. Such submarines are no longer manufactured in the United States and this has given rise to cost issues and concerns over potential leaks of sensitive U.S. submarine secrets if manufacturing were to be contracted out to Taiwanese and European companies (Kan 2014; Fang 2004).

One of the issues related to the implementation of the TRA is the extent to which U.S. commitments to Taiwan's defense is linked to maintaining a military balance across the Strait. When the TRA was enacted in 1979, Taiwan did not face a significant military imbalance; if anything one could argue it enjoyed aerial superiority. Maintaining that qualitative edge therefore provided the rationale and benchmark for U.S. decisions on what defense articles to sell to Taiwan. However, China's economy has registered phenomenal growth since the early 1980s and with consistently double-digit increases in defense spending over the past two decades and the concurrent military modernization programs, the military balance has been shifting to the mainland's favor. At the same time, Beijing's geopolitical influence has also been on the rise and this has led to growing concern over a fading U.S. commitment to maintain the cross-Strait balance (Hsiao 2014; Sutter 2009; Cheng 2010). Indeed, the past two decades since the 199596 Taiwan Strait crisis have seen steady growth in China's military capabilities. While the United States still holds some advantages in qualitative terms, that superiority has gradually diminished to the extent that future conflicts with China over Taiwan could inflict significant costs on the U.S. forward deployed forces. As a recent RAND report points out, "the problem of defending Taiwan has become significantly more difficult for the United States since 1996. Relative capabilities are likely to continue shifting against the United States, at least as long as economic trends favor China" (Heginbotham et al. 2015, 332).

Advocates for sustaining a cross-Strait military balance maintain that only when Taiwan has sufficient defense capabilities can it negotiate with the mainland from a position of strength, and certainly at a minimum would be able to withstand Chinese military assaults long enough so that the United States could come to its assistance. There are also deeper reasons as well. Taiwan has become a democracy; Washington has its credibility at stake if it fails to defend Taiwan should an unprovoked attack befall the island. Another concern with the military balance has always been that with the mainland continuing to build 
up its military capabilities, it would be in a position to coerce Taiwan to accept a political settlement on Beijing's terms. This would be considered by Washington as unilateral change of the status quo across the Taiwan Strait (Stokes and Tsai 2016). This being the case, the U.S. defense relationship with Taiwan, in the words of assistant defense secretary Peter Rodman, "seeks to reverse the negative trends in its ability to defend itself, thereby decreasing the prospects that U.S. military intervention would be necessary in a crisis. The goal is to strengthen deterrence" (Rodman 2004). Within this context, recent years have witnessed growing concerns and frustration among U.S. officials and analysts over the lack of sufficient funds for defense in Taiwan to enable the island state to maintain adequate defense. At the same time, Taiwan's national security policymaking and weapons procurement processes have raised further questions on effective formulation and implementation of coordinated defense modernization programs (Swaine 1999; Chase 2008).

However, sustaining long-term military balance across the Taiwan Strait would encounter serious political, resource, and military obstacles. To begin with, if such a balance is solely calculated in military terms, it means that Taiwan, with a much smaller economic base and much smaller defense budget, will have to maintain a certain level of expenditure to barely keep up with China's military modernization programs, as Beijing becomes capable of spending more by basically keeping its defense budget at a certain percentage of its quickly growing overall GDP, which overtook Japan's in 2010 to become the second largest economy in the world. China spends, even using Beijing's official figures, thirteen times more than Taiwan spends on defense (in 2015, China's defense budget was $\$ 141.9$ billion while Taiwan's spent $\$ 10.9$ billion) (USCC 2015, 509). As a result, seeking to maintain a military balance risks an arms race in which Taiwan would find it hard to keep up, much less win. Consequently this is not an appealing proposition for political reasons and is hardly sustainable financially; over the long term, without properly defining what objectives such a military balance is meant to achieve, continuing such an arms race would only further deepen the security dilemma and raise the costs for all involved (Wachman 2007).

Taiwan's defense transformation over the past few years, which seeks to make the transition from the current conscription system to an all-volunteer force (AVF), has not proceeded smoothly. The objective of such reforms, according to Taiwan's defense ministry, is to create a "small but smart and strong force" in response to "the requirement for high quality manpower under advanced technological conditions and economic and social changes" (MND/ROC 2013, 79). However, a number of issues have since arisen, such as the failure to meet the originally set recruitment targets (even with higher salaries and hardship post bonuses as incentives) resulting in the lowering of annual recruitment targets, with a planned active force of about 170,000 by 2019 , reduced from the original 215,000 . Other issues include the unanticipated higher expenses incurred in 
supporting a professional military (USCC 2015; Cole 2015; Thim and Liao 2016). Some have suggested that one way of addressing these issues would be a more clearly defined strategy for Taiwan's military, which should place more emphasis on deterring the Chinese military with asymmetrical tactics rather than full engagement (Easton 2014; Murray 2015).

In sum, while cross-Strait relations have witnessed significant improvement in economic and diplomatic spheres since Ma took office in May 2008, Taiwan's security environment and its ability to defend itself vis-à-vis the mainland continues to erode as China's military capabilities increase. For instance, Taiwan is losing its superiority over the region's airspace and China's growing number of ballistic and cruise missiles threaten to overwhelm and paralyze the island's inadequate air-defense systems. While Taiwan maintains about 400 combat aircraft, the actual number of those which are operationally capable is far fewer. At the same time, Taiwan's foreign-purchased fighter aircraft are suffering from a lack of spare parts and service (USCC 2010, 143-159).

\section{China's Rise and U.S. Taiwan Policy}

China's re-emergence as a great power over the past two decades has significantly transformed the global and regional geo-economic and geo-political landscapes. Since 2008, when the world was engulfed in massive economic and financial calamities, the Chinese economy, albeit growing at a much slower rate of between 6.5 and 7.5 percent (compared to the phenomenal double-digit growth rate over the previous three decades), has weathered the crisis and come out relatively intact and stronger compared to most major industrialized countries. By 2010, China had overtaken Japan to become the second largest economy in the world. China is also closing the gap between it and the United States. In 2001, China's GDP was less than 13 percent of U.S. GDP; a decade later, it had grown to 50 percent. This further narrowed to about 61 percent in 2015 . Using purchasing power parity (PPP) exchange rates, in 2015 China's GDP (\$20.853 trillion) surpassed U.S. GDP (\$18.558 trillion) to become the largest economy in the world (Knoema 2016). The rise of China is transforming the geopolitical landscape of the Indo-Pacific region. With growing economic power, financial resources, and military capabilities, Beijing has become more assertive in its pursuit of national interests, in particular with regard to territorial disputes in the East and South China Seas; become more involved in regional and global affairs from climate change to major infrastructure initiatives and new financial institutions; and is actively engaging diplomatically in multilateral forums and great-power relationships, including with the United States. Increasingly, Beijing is perceived to be aiming at undermining U.S. predominance in the region and striving to regain its own sphere of influence (Friedberg 2011). 
How the United States and China manage their relationship in the coming years will affect to a significant extent whether peace, stability, and prosperity will continue in the Indo-Pacific region, including cross-Strait relations, or if the region will be overshadowed by U.S.-China rivalry for primacy, resulting in tension, conflict, or even military clashes between the two great powers. Despite the growing economic interdependence and a multitude of official dialogues between Beijing and Washington, bilateral ties have been strained in recent years due to major differences over a range of issues even as the two countries continue to cooperate on others. According to power transition theory, and given the stakes in the region, U.S.-China confrontation is inevitable (Biddle and Oelrich 2016).

One of the recurring tensions in bilateral relations is U.S. arms sales to Taiwan. Beijing argues that this remains a serious impediment to improving bilateral ties. Between 2001 and 2015, the U.S. approved close to $\$ 21$ billion in arms sales to Taiwan; during the same period $\$ 5.1$ billion arms were delivered (Kan 2014; SIPRI 2016; Forsythe 2015). President Bush's decision to approve $\$ 6.5$ billion in arms sales and his controversial "whatever it took to help defend Taiwan" statement early in his administration (April 2001) strained bilateral relations. Chinese Defense Minister General Liang Guanglie reacted strongly when the Bush administration in 2008 announced $\$ 6.4$ billion in delayed arms sale to Taiwan, demanding that it be cancelled. General Liang argued that such a move created serious obstacles for military to military exchanges (Bodeen 2008). After President Obama announced a $\$ 6.4$ billion arms deal to Taipei in 2010, the PLA cut off most contact with the Pentagon. Some Chinese analysts and retired PLA officers even suggested that China should impose sanctions on those companies involved in arms exports to Taiwan.

The rise of China has generated wide-ranging discussions and speculation on how Beijing will use its growing power resources, including economic and military capabilities, political influence, and "soft power," to advance its interests in both regional and global settings and how a rising and presumably more assertive China will challenge the dominant position of the United States in Asia (Friedberg 2011; Christensen 2015). With the changing military balance across the Taiwan Strait, and increasingly also in Western Pacific, serious questions have been raised regarding U.S. Taiwan policy, in particular with regard to its commitment to the latter's security, and the extent to which such commitment could and should be maintained at all, and at what costs. Some prominent analysts have argued for a reduced U.S. commitment to Taiwan's defense or even abandonment of the latter; others have advocated for grand bargains between Washington and Beijing where U.S. concessions are traded for Chinese recognition and support of American interests in the region and globally (Mearsheimer 2014; C. Glaser 2015; Goldstein 2015). Still others reject the abandonment suggestion and argue strongly that instead of weakening U.S. relations with Taiwan, greater effort should be 
expended in enhancing Washington's economic, security, and diplomatic ties with Taipei, and encouraging and supporting Taiwan's role in and cooperation with regional economic and security organizations and like-minded partners. Only by so doing can the United States respond effectively to Chinese assertiveness and hence maintain its dominant position in Asia and beyond (Easton 2016; Stokes and Tsai 2016; Krejsa 2016).

The U.S. responses to the rise of China have been generally characterized as the pivot or rebalance to Asia. With the Afghanistan and Iraq Wars drawing down and to a close, and recognizing that Washington's neglect of the region had caused concerns about and resulted in the loss of credibility of America's commitments to its allies and friends, the Obama Administration has undertaken a series of diplomatic, economic, and military initiatives to restore confidence and demonstrate its resolve that America has always been and remains an indispensable Pacific power (Clinton 2011). Diplomatically, Obama and highranking officials such as Secretary of State Hillary Clinton have devoted time and resources to Asia. Economically, the United States joined and has become a leading force in the twelve-nation Trans-Pacific Partnership (TPP) multilateral free trade negotiations to develop a twenty-first century trade agreement, and to regain America's economic leadership position in the region (Dai 2015). In the military arena, the rebalance has involved the repositioning of 60 percent of U.S. air and naval power to the region by 2020 , the strengthening of its alliances and the development of new security partnerships, and the development of concepts and operational capabilities such as AirSea Battle in response to China's antiaccess/area denial A2/AD posture (Harold 2015; Biddle and Oelrich 2016).

One of the issues directly affecting Taiwan's defense capabilities is the extent to which changing U.S.-China relations can and have affected how the TRA is implemented, especially with regard to arms sales and the overall defense ties between Washington and Taipei (Lee 2010). As pointed out above, the Bush administration came into office with a strong policy mandate to strengthen alliance relations and support Taiwan. In April 2001, President Bush approved an arms sale package to Taiwan just a few months after assuming office. This was the single largest deal since Washington and Beijing signed the August 17, 1982 joint statement, and included diesel-electric submarines, anti-submarine warfare aircraft, and anti-ship cruise missiles. However, since late 2003, the Bush administration notably reversed its earlier, more pro-Taiwan policy as the Chen Shui-bian government engaged in high-profile and extremely risky tactics of moving Taiwan toward de jure independence that not only riled Beijing but also threatened Washington's national security priorities in combating global terrorism and the spread of weapons of mass destruction (WMDs) that required close cooperation with China. In stark contrast to his statements in 2001, President Bush noted in December 2003 that Washington staunchly opposed "any unilateral decision by either China or Taiwan to change the status quo" (Pomfret 
2003).

Indeed, since the April 2001 "whatever it takes" statement, U.S. administration officials, and Presidents Bush and Obama, have made it clear that Washington's commitments to Taiwan's defense are not a carte blanche and must serve the broader U.S. interests of peace and stability in the region, which increasingly means the maintenance of the status quo across the Taiwan Strait, where neither side should take unilateral actions detrimental, or seen as such, to the status quo. The larger question relates to obligations and responsibilities not just from the U.S. side but also from Taiwan's side, especially as the island undergoes further democratization, which in turn affects how the status quo is viewed and can be maintained. For instance, Deputy Undersecretary of Defense Richard Lawless, in a prepared speech delivered at the 2005 Defense Industry Conference of the U.S.-Taiwan Business Council, declared that "for too long, the Taiwan Relations Act has been referenced as purely a U.S. obligation.... Under the TRA, the U.S. is obligated to 'enable' Taiwan to maintain a sufficient selfdefense, but the reality is, it is Taiwan that is obligated to have a sufficient selfdefense" (Kan 2014, 28). To that effect, U.S. officials over the past few years have expressed apparent frustration with declining defense budgets and the impasse in allocating special funds to purchase approved U.S. arms due to partisan bickering in the Taiwanese legislature.

Indeed, there are clear indications that the executive branch since late 2003 has worked closely with Beijing to avoid allowing potential conflict over Taiwan to get in the way of general U.S.-China relations. So much so that one analyst contended that as Washington needs Beijing's cooperation on a range of issues, "both the Bush and Obama Administrations have tended to view Taiwan as a problem to be managed, not a valuable ally with strategic implications for the future of China" (Fisher 2010). Washington and Beijing recognize that the issues of Taiwan and cross-Strait tension can cause significant conflict and therefore call for increased strategic dialogue between political and military leaders to avoid misunderstandings over Taiwan. This larger context explains the lack of major U.S. arms sales package to Taiwan until the October 2008 offer. Indeed, given the stalemate in defense appropriations in Taiwan during much of Chen's second term and the lack of U.S. decisions on sizable sales, some analysts are raising questions about Taiwan's ability to defend itself as well as Washington's credibility and commitment.

Meanwhile, as Ma's mainland policy drew the island closer to China, Taipei at times ran into conflict with Washington's strategic interests in Asia. This became obvious as the Ma administration's positions on territorial disputes appeared to be aligned with those of Beijing. However, the more worrisome development, as the Obama administration views it, is the danger that Taipei could become vulnerable as its economic dependence on the mainland deepens (Chen 2016). 
The implementation of the TRA has therefore been linked to the broader issue of how to formulate U.S. Taiwan policy in ways that would advance America's overall interests in the region-strong alliances, stability, and continued U.S. primacy-without being entrapped by inflexible commitments and hence the risk of being dragged into conflicts with China or other potential adversaries (Chan 2010; Ong 2010). The policy of strategic ambiguity, which is supposedly meant as a double deterrent against both China and Taiwan, runs the risk of being misinterpreted by Beijing and Taipei, and indeed one could argue the policy is deliberately misrepresented at times (Christensen 2002; Pan 2003). However, despite calls for greater clarity, on balance, the policy has served U.S. interests well and in general contributed to cross-Strait stability. In fact, succeeding administrations have for all practical purposes carried out policies that span over the spectrum of clarity at one end and ambiguity at the other (Hsu 2010; Kastner 2006). Despite recent debates among American Taiwan specialists on whether Washington should discontinue arms sales to Taiwan in exchange for a grand bargain with Beijing, or accept the "Finlandization" of Taiwan by China (C. Glaser 2015; Gilley 2010), the mainstream U.S. view is that Taiwan remains a critical linchpin in its "Pivot to Asia" strategy and an important strategic asset in the first island chain. Indeed, Kurt Campbell, former Assistant Secretary of State during the first term of the Obama administration and one of the architects of the U.S. pivot to Asia policy, argues that U.S.-Taiwan relations form an important component of American strategy in Asia. He maintains that Washington should continue to encourage cross-Strait dialogue but also show its support of Taipei's efforts to diversify its external economic ties and its membership in international organizations where statehood is not a requirement. But perhaps most importantly, the United States must maintain and improve bilateral security arrangements through arms sales and encourage Taipei to strengthen its defense (Campbell 2016, 255-258).

\section{Conclusion}

Three broad conclusions can be drawn from the above analysis. First, the past eight years since the Ma Ying-jeou government came into power in 2008 have seen significant improvement in cross-Strait relations. The reduction of tension has allowed resumption and expansion of bilateral dialogue and the institutionalization of interflows between the two sides. Growing exchanges and expansion in trade, investment, and people have in general been conducive to peace and stability across the Taiwan Strait and have in turn contributed to regional security. Beijing, Taipei, and Washington have welcomed and helped promote these positive developments. However, sustaining long-term stability and moving beyond the "low hanging fruit" to engaging in substantive political 
negotiation between Beijing and Taipei remains a yet-to-be realized cross-Strait agenda. And with the DPP's Tsai now in power, the prospect becomes even more remote. Given the emerging U.S.-China rivalry in the Asia-Pacific and Taiwan's growing importance in Washington's pivot strategy, managing the complex relationships among the three players requires innovative thinking and proactive actions from all three countries so that a positively reinforcing triangle can be developed (Womack and Hao 2016).

Second, despite progress in cross-Strait relations over the past eight years, many key issues remain unresolved. These concern the divergent interpretations, expectations, and long-term goals of Beijing and Taiwan. While the KMTdominated government accepted the 1992 Consensus as a pre-condition for bilateral exchanges, it had a completely different notion from Beijing of what the One China principle represents. At the same time, the gap in perceptions, expectations, and policy goals became more apparent when the two sides started to tackle tougher issues ranging from Taiwan's demand for greater international space and reduction of military threats from the mainland, including the missiles deployed across the Strait, to Beijing's interest in seeing its economic largess yielding political dividends. With Tsai winning the 2016 Taiwan presidential election, it is not out of the question that tensions may return to cross-Strait relations as Beijing demands-and Taipei refuses-a formal embrace of the 1992 Consensus. While the overall trend may favor stability, one cannot assume that the Taiwan Strait is no longer a flash point in Asia (Lee and Schreer 2016; Kastner 2015/16).

And finally, there is no guarantee that the security environment across the Taiwan Strait will remain in its current stable state. Indeed, the temporary stable situation across the Taiwan Strait, or what scholars characterize as "negative" peace, remains fragile and more effort is required to foster, promote, and sustain a "positive" peace (Diehl 2016). China is continuing its military modernization not only to dominate any potential future conflict with the island, but increasingly also seeks to impose significant costs on the United States should it contemplate intervention in a cross-Strait crisis. With China's rise and the U.S. need to enlist Beijing's cooperation on many global and regional issues, Washington could become ever more cautious in fulfilling its security commitments to Taiwan, including the supply of arms requested by Taipei. This leaves Taiwan vulnerable to an ever assertive China that could make a (mis)calculation in its unification game plan. The growing imbalance across the Taiwan Strait requires Washington to recalibrate its policy toward both Taipei and Beijing in order to maintain stability (Hsiao 2014).

Taiwan's ultimate recourse in securing its sovereignty and autonomy lies not so much in its military capabilities-although it needs a strong defense to withstand and defeat intimidation if not full-fledged military assaults from the mainland-rather in a national security strategy that integrates effective 
soft power diplomacy, its democratic credentials, and its value as an economic partner, to engage the international community, the United States, its regional allies, and, ultimately, its nemesis mainland China. This will be a major test for the Tsai administration and the stakes could not be higher.

\section{References}

Albert, Eleanor. 2016. “China-Taiwan Relations.” CFR Backgrounders, Council on Foreign Relations, May 18. http://www.cfr.org/china/china-taiwan-relations/p9223 (accessed August 16, 2016).

Babones, Salvatore. 2016. "One China, One Taiwan: Little Chance of a Red Future for Taipei." Foreign Affairs, January 12. https://www.foreignaffairs.com/articles/ taiwan/2016-01-12/one-china-one-taiwan (accessed October 14, 2016).

Biddle, Stephen, and Ivan Oelrich. 2016. "Future Warfare in the Western Pacific: Chinese Antiaccess/Area Denial, U.S. AirSea Battle, and Command of the Commons in East Asia." International Security 41 (1): 7-48.

Blanchard, Jean-Marc F., and Simon Shen, eds. 2015. Conflict and Cooperation in SinoUS Relations: Change and Continuity, Causes and Cures. London and New York: Routledge.

Bodeen, Christopher. 2008. "China Defense Minister Raps US Arms Sale to Taiwan.” Washington Post, October 14.

Bräuner, Oliver, Mark Bromley, and Mathieu Duchâtel. 2015. Western Arms Exports to China. SIPRI Policy Paper No. 43. Stockholm: Stockholm International Peace Research Institute.

Bush, Richard C. 2005. Untying the Knot: Making Peace in the Taiwan Strait. Washington, DC: The Brookings Institution.

Bush, Richard C. 2011. "Taiwan and East Asian Security." Orbis 55 (2): 274-289.

Bush, Richard C. 2013. Uncharted Strait: the Future of China-Taiwan Relations. Washington, DC: The Brookings Institution.

Bush, Richard C. 2016. "Decoding Xi Jinping's Latest Remarks on Taiwan.” The Brookings Institution, March 17. https://www.brookings.edu/blog/order-from-chaos/2016/ 03/17/decoding-xi-jinpings-latest-remarks-on-taiwan/ (accessed August 16, 2016).

Cai, Kevin G., ed. 2011. Cross-Taiwan Straits Relations since 1979: Policy Adjustment and Institutional Change Across the Straits. Singapore: World Scientific Publishing Co.

Campbell, Kurt M. 2016. The Pivot: The Future of American Statecraft in Asia. New York: Twelve.

Chan, Steve. 2010. "The Taiwan Relations Act Considered from Alternative Perspectives." Issues \& Studies 46 (3): 1-27.

Chase, Michael S. 2005. "U.S.-Taiwan Security Cooperation: Enhancing an Unofficial Relationship." In Dangerous Strait: The U.S.-Taiwan-China Crisis, edited by Nancy Bernkopf Tucker, 162-185. New York: Columbia University Press.

Chase, Michael S. 2008. “Taiwan's Arms Procurement Debate." Asian Survey 48 (4): 703 724.

Chen, Dean P. 2016. “US-China Rivalry and the Weakening of the KMT’s '1992 Consensus' 
Policy." Asian Survey 56 (4): 754-778.

Cheng, Dean. 2010. "Meeting Taiwan's Self-Defense Needs." Backgrounder No. 2379, The Heritage Foundation, February 26. http://www.heritage.org/research/reports/2010/02/ meeting-taiwans-selfdefense-needs (accessed February 12, 2015).

Chiao, Yuan-Ming. 2016. "Chinese Visitors May Drop by 1/2: Reports." The China Post, January 23. http://www.chinapost.com.tw/taiwan/china-taiwan-relations/2016/01/23/ 456816/Chinese-visitors.htm (accessed August 16, 2016).

Christensen, Thomas J. 2015. The China Challenge: Shaping the Choices of a Rising Power. New York: W.W. Norton.

Christensen, Thomas J. 2002. “The Contemporary Security Dilemma: Deterring a Taiwan Conflict." The Washington Quarterly 25 (4): 7-21.

Cliff, Roger. 2015. China's Military Power: Assessing Current and Future Capabilities. New York: Cambridge University Press.

Cliff, Roger, Mark Burles, Michael S. Chase, Derek Eaton, and Kevin L. Pollpeter. 2007. Entering the Dragon's Lair: Chinese Antiaccess Strategies and Their Implications for the United States. Santa Monica, CA: RAND.

Clinton, Hillary Rodman. 2011. “America’s Pacific Century." Foreign Policy 189: 56-63.

Cole, J. Michael. 2015. “Taiwan's All-Volunteer Force Pains: There's a Way Out." The Diplomat, April 24. http://thediplomat.com/2015/04/taiwans-all-volunteer-forcepains-theres-a-way-out/ (accessed April 30, 2015).

Crookes, Paul Irwin. 2016. "The Political and Security Nexus of the Taiwan Strait and China’s New Military Capabilities.” The RUSI Journal 161 (2): 48-55.

Dai, Xinyuan. 2015. "Who Defines the Rules of the Game in East Asia? The Trans-Pacific Partnership and the Strategic Use of International Institutions." International Relations of the Asia-Pacific 15 (1): 1-25.

deLisle, Jacques. 2016. Taiwan's Quest for International Space: Ma’s Legacy, Tsai’s Options, China's Choices, and U.S. Policy." Orbis: A Journal of World Affairs 60 (4): 550-574.

DOD (Department of Defense). 2010. "Military and Security Developments involving the People's Republic of China." Annual Report to Congress, August 17. http://www. defense.gov/pubs/pdfs/2010_CMPR_Final.pdf (accessed August 18, 2010).

DOD (Department of Defense). 2016. "Military and Security Developments Involving the People's Republic of China." Annual Report to Congress, May 13. http://www.defense. gov/Portals/1/Documents/pubs/2016\%20China\%20Military\%20Power\%20Report. pdf (accessed May 14, 2016).

Diehl, Paul F. 2016. "Exploring Peace: Looking Beyond War and Negative Peace.” International Studies Quarterly 60 (1): 1-10.

Easton, Ian. 2014. "Able Archers: Taiwan Defense Strategy in an Age of Precision Strike." Project 2049 Institute, September. http://www.project2049.net/documents/Easton_ Able_Archers_Taiwan_Defense_Strategy.pdf (accessed August 9, 2016).

Easton, Ian. 2016. “Strategic Standoff: The U.S.-China Rivalry and Taiwan.” Project 2049 Institute, March. http://www.project2049.net/documents/Strategic\%20Standoff_US_ China_Rivalry_Taiwan.pdf (accessed July 25, 2016).

Erickson, Andrew S., and Jingdong Yuan. 2011. "Antiaccess and China's Air-Launched Cruise Missiles.” In Chinese Aerospace Power: Evolving Maritime Roles, edited by Andrew S. Erickson and Lyle J. Goldstein, 275-286. Annapolis, MD: Naval Institute Press. 
Fang, Hsu-hsiung. 2004. “The Transformation of U.S.-Taiwan Military Relations.” Orbis 48 (3): 551-561.

Fisher, Richard Jr. 2010. "Sustaining Deterrence on the Taiwan Strait." International Assessment and Strategic Center, July 21. http://www.strategycenter.net/research/ pubID.228/pub_detail.asp (accessed September 11, 2010).

Forsythe, Michael. 2015. "China Protests Sales of U.S. Arms to Taiwan." New York Times, December 17.

Friedberg, Aaron L. 2011. A Contest for Supremacy: China, America, and the Struggle for Mastery in Asia. New York: W.W. Norton.

Gilley, Bruce. 2010. "Not So Dire Straits: How the Finlandization of Taiwan Benefits U.S. Security." Foreign Affairs 89 (1): 44-60.

Glaser, Bonnie S. 2012. "U.S.-China-Taiwan Relations in the Run-up to 2012 Elections in Taiwan and the U.S. and Leadership Transition in China." Paper presented at the conference on Facing the Challenges of Cross-Strait Relations, Carnegie Endowment of International Peace, Washington D.C., July.

Glaser, Bonnie S. 2015. “The PLA Role in China's Taiwan Policymaking." In PLA Influence on China's National Security Policymaking, edited by Phillip C. Saunders and Andrew Scobell, 166-197. Stanford: Stanford University Press.

Glaser, Bonnie S. 2016. "Prospects for Cross-Strait Relations as Tsai Ing-wen Assumes the Presidency in Taiwan." CSIS China Power Project, Center for Strategic and International Studies, April. https://csis-prod.s3.amazonaws.com/s3fs-public/ publication/160418_Glaser_ProspectsCrossStraitRelations_Web.pdf (accessed August 10, 2016).

Glaser, Bonnie, and Brad Glosserman. 2008. "Promoting Confidence Building across the Taiwan Strait." Center for Strategic and International Studies, September. https:// csis-prod.s3.amazonaws.com/s3fs-public/legacy_files/files/media/csis/pubs/080910_ glaser_promotingconfidence_web.pdf (accessed February 14, 2015).

Glaser, Bonnie S., and Jacqueline Vitello. 2015. "Xi Jinping's Great Game: Are China and Taiwan Headed toward Trouble?" The National Interest, July 16. http:// nationalinterest.org/feature/xi-jinpings-great-game-are-china-taiwan-headedtowards-13346 (accessed October 14, 2016).

Glaser, Charles L. 2015. "A U.S.-China Grand Bargain? The Hard Choice between Military Competition and Accommodation." International Security 39 (4): 49-90.

Glosny, Michael A. 2011. "Getting beyond Taiwan? Chinese Foreign Policy and PLA Modernization." Strategic Forum 261 Institute for National Strategic Studies, National Defense University, January. http://ndupress.ndu.edu/Portals/68/Documents/ stratforum/SF-261.pdf (accessed January 31, 2011).

Goldstein, Lyle J. 2015. Meeting China Halfway: How to Defuse the Emerging US-China Rivalry. Washington, D.C.: Georgetown University Press.

Goldstein, Steven M., and Randall Schriver. 2001. "An Uncertain Relationship: The United States, Taiwan and the Taiwan Relations Act." The China Quarterly 165: 147-172.

Harold, Scott W. 2015. "Is the Pivot Doomed? The Resilience of America's Strategic 'Rebalance." The Washington Quarterly 37 (4): 85-99.

Heginbotham, Eric, Michael Nixon, Forrest E. Morgan, Jacob L. Heim, Jeff Hagen, Sheng Li, Jeffrey Engstrom, Martin C. Libicki, Paul DeLuca, David A. Shlapak, David R. Frelinger, Burgess Laird, Kyle Brady, and Lyle J. Morris. 2015. The U.S.-China 
Military Scorecard: Forces, Geography, and the Evolving Balance of Power, 1996-2017. Washington, D.C.: RAND Corporation.

Hickey, Dennis V. 2015. "Parallel Progress: US-Taiwan Relations During an Era of CrossStrait Rapprochement." Journal of Chinese Political Science 20 (4): 369-384.

Hickey, Dennis V., and Emerson Niou. 2016. “Taiwan in 2015: A Turning Point?” Asian Survey 56 (1): 57-67.

Hsiao, Russell. 2014. "U.S.-Taiwan Relations: Hobson's Choice and the False Dilemma." In Strategic Asia 2014-15: U.S. Alliances and Partnerships at the Center of Global Power, edited by Ashley J. Tellis, Abraham M. Denmark, and Greg Chaffin, 258-287. Seattle, WA: The National Bureau of Asian Research.

Hsu, S. Philip. 2010. "Reappraising the Debate and Practice of US Strategic Ambiguity/ Clarity in Cross-Strait Relations." Pacific Review 23 (2): 139-162.

Hsueh, Roselyn. 2014. “Taiwan's Treaty Trouble: The Backlash Against Taipei’s China Deal." Foreign Affairs, June 3. https://www.foreignaffairs.com/articles/china/2014-06-03/ taiwans-treaty-trouble (accessed October 14, 2016).

Huang, Alexander Chieh-Cheng. 2010. “The United States and Taiwan's Defense Transformation.” Taiwan-U.S. Quarterly Analysis, The Brookings Institution, February 16. https://www.brookings.edu/opinions/the-united-states-and-taiwansdefense-transformation/ (accessed November 28, 2010).

Huang, Alexander Chieh-cheng. 2011. "A Midterm Assessment of Taiwan's First Quadrennial Defense Review." The Brookings Institution, February 8. https://www. brookings.edu/research/a-midterm-assessment-of-taiwans-first-quadrennialdefense-review/ (accessed August 8, 2011).

Huang, Cary. 2016. "Does Taiwan Still Matter for Mainland China?" South China Morning Post, January 16. http://www.scmp.com/print/comment/insight-opinion/ article/1901786/does-taiwan-still-matter-mainland-china (accessed August 16, 2016).

IISS (The International Institute for Strategic Studies). 2016. The Military Balance 2016: the Annual Assessment of Global Military Capabilities and Defence Economics. London: Routledge for IISS.

Knoema. 2016. “World GDP Ranking 2016." https://knoema.com/nwnfkne/world-gdpranking-2016-data-and-charts-forecast (accessed September 25, 2016).

Kan, Francis Yi-hua. 2013. "The Prospects for Cross-Taiwan Strait Confidence Building Measures: Opportunities and Challenges." In New Dynamics in Cross-Strait Relations: How Far Can the Rapprochement Go?, edited by Weixin Hu, 78-96. London: Routledge.

Kan, Shirley. 2014. “Taiwan: Major U.S. Arms Sales since 1990.” CRS Report RL30975, Congressional Research Service, August 29. https://www.fas.org/sgp/crs/weapons/ RL30957.pdf (accessed October 31, 2014).

Kan, Shirley A., Christopher Bolkcom, and Ronald O’Rourke. 2001. “China’s Foreign Conventional Arms Acquisitions: Background and Analysis." Congressional Research Service, November 6. http://www.dtic.mil/dtic/tr/fulltext/u2/a463064.pdf (accessed October 26, 2016).

Kan, Shirley A., and Wayne M. Morrison. 2014. "U.S.-Taiwan Relationship: Overview of Policy Issues.” CRS Report R41952, Congressional Research Service, December 11. http://www.fas.org/sgp/crs/row/R41952.pdf (accessed August 10, 2016).

Kastner, Scott L. 2006. "Ambiguity, Economic Interdependence, and the US Strategic 
Dilemma in the Taiwan Strait." Journal of Contemporary China 15 (49): 651-669.

Kastner, Scott L. 2009. Political Conflict and Economic Interdependence Across the Taiwan Strait and Beyond. Stanford: Stanford University Press.

Kastner, Scott L. 2015/16. "Is the Taiwan Strait Still a Flash Point? Rethinking the Prospects for Amred Conflict between China and Taiwan.” International Security 40 (3): 54-92.

Keng, Shu, and Gunter Schubert. 2010. "Agents of Taiwan-China Unification? The Political Roles of Taiwanese Business People in the Process of Cross-Strait Integration." Asian Survey 50 (2): 287-310.

Kok, Piin-Fen, and David J. Fiestein. 2013. “Threading the Needle: Proposals for U.S. and Chinese Actions on Arms Sales to Taiwan.” EastWest Institute, September 10. https:// www.eastwest.ngo/idea/threading-needle-proposals-us-and-chinese-actions-armssales-taiwan (accessed October 7, 2014).

Krejsa, Harry. 2016. "Seeing Strait: The Future of the U.S.-Taiwan Strategic Relationship." Center for a New American Security. May 18. https://www.cnas.org/publications/ reports/seeing-strait-the-future-of-the-u-s-taiwan-strategic-relationship (accessed May 27, 2016).

Krepinevich, Andrew Barry Watts, and Robert Work. 2003. "Meeting the Anti-Access and Area-Denial Challenge." Center for Strategic and Budgetary Assessments, May 20. http://csbaonline.org/research/publications/a2ad-anti-access-area-denial (accessed June 17, 2015.

Lam, Willy. 2016. "After the Election: The Future of Cross-Strait Relations." China Brief 16 (1): 3-6.

Lee, John. 2011. "Why Taiwan will Fail." Wall Street Journal, March 31.

Lee, Sheryn, and Ben Schreer. 2016. "Time to Start Worrying Again? Cross-Strait Stability after the 2016 Taiwanese Elections.” Strategic Insights, Australian Strategic Policy Institute, March. https://www.aspi.org.au/publications/time-to-start-worrying-again/ SI104_Taiwan.pdf (accessed August 10, 2016).

Lee, Wei-chin. 2000. "US Arms Transfer Policy to Taiwan: from Carter to Clinton." Journal of Contemporary China 9 (23): 53-75.

Lee, Wei-chin. 2010. "Arms Twisting: U.S.-Taiwan Arms Transfers in the First Decade of the Twenty-first Century." Issues \& Studies 46 (3): 151-186.

Liao, Nien-chung Chang. 2012. "Building Trust across the Taiwan Strait: A Strategy of Reassurance." Issues \& Studies 48 (3): 105-145.

Liao, Nien-chung Chang. 2014. "Comparative Inter-Korean and Cross-Taiwan Strait TrustBuilding: The Limits of Reassurance." Asian Survey 54 (6): 1037-1058.

Lin, Gang. 2016. "Beijing's New Strategies toward a Changing Taiwan." Journal of Contemporary China 25 (99): 321-335.

McNeil, Kirstin. 2008. "Long-Delayed Arms Sales to Taiwan Announced." Arms Control Today 38 (9): 29-30.

Mearsheimer, John J. 2014. “Taiwan's Dire Straits.” The National Interest 130: 29-39.

Mei, Fu S. 2011. "Taiwan's Defense Transformation and Challenges under Ma Ying-jeou." The China Brief 11 (7): 7-9.

Meltzer, Joshua. 2014. “Taiwan's Economic Opportunities and Challenges and the Importance of the Trans-Pacific Partnership." East Asia Policy Paper 2, The Brookings Institution, January. https://www.brookings.edu/wp-content/uploads/2016/06/ taiwan-trans-pacific-partnership-meltzer-012014.pdf (accessed August 16, 2016). 
MND/ROC (Ministry of National Defense, Republic of China). 2013. "National Defense Report 2013.” October. http://www.us-taiwan.org/reports/2013_october_taiwan_ national_defense_report.pdf (accessed August 11, 2016).

MND/ROC (Ministry of National Defense, Republic of China). 2015. "National Defense Report 2015." November. http://report.mnd.gov.tw/pageeb46.html?sn=1\&lang=en (accessed August 11, 2016).

Minnick, Wendell. 2010. “Taipei Gets \$6 Billion Arms Package Despite Beijing Threats.” Wendell Minnick - Articles (blog), February 11. http://minnickarticles.blogspot. kr/2010/02/taipei-gets-6-billion-arms-package.html (accessed October 31, 2016).

Minnick, Wendell. 2011. “U.S. to Deny Taiwan New F-16 Fighters.” Wendell Minnick Articles (blog), August 31. http://minnickarticles.blogspot.kr/2011/08/us-to-denytaiwan-new-jets.html (accessed October 31, 2016).

Moore, Gregory J. 2016. “The Power of 'Sacred Commitments': Chinese Interests in Taiwan." Foreign Policy Analysis 12 (2): 214-235.

Mulvenon, James, and David M. Finkelstein, eds. 2005. China's Revolution in Doctrinal Affairs: Emerging Trends in the Operational Art of the Chinese People's Liberation Army. Alexandria, VA: Center for Naval Analyses.

Murray, William S. 2015. "Asymmetric Options for Taiwan's Deterrence and Defense." In Globalization and Security Relations across the Taiwan Strait, edited by Monique Ming-chin Chu and Scott L. Kastner, 61-79. London: Routledge.

Ong, Russell. 2010. “Taiwan's Strategic Options and the US." Asia-Pacific Review 17 (2): 5675.

Pan, Zhongqi. 2003. "U.S. Taiwan Policy of Strategic Ambiguity: A Dilemma of Deterrence." Journal of Contemporary China 12 (35): 387-407.

Pomfret, John. 2003. "China Lauds Bush for Comments on Taiwan." Washington Post, December 12.

Rigger, Shelley. 2013. “Taiwan in U.S.-China Relations.” In Tangled Titans: The United States and China, edited by David Shambaugh, 293-311. Lanham: Rowman \& Littlefield Publishers, Ltd.

Rodman, Peter W. 2004. "Prepared statement of the Honorable Assistant Secretary for International Security Affairs, Department of Defense." Hearing before the Committee on International Relations, House of Representatives, 108th Congress, 2nd Session, “The Taiwan Relations Act: The Next Twenty-Five Years," April 21.

Romberg, Alan D. 2016. “Tsai Ing-wen Takes Office: A New Era in Cross-Strait Relations.” China Leadership Monitor 50, July 19. http://www.hoover.org/research/tsai-ing-wentakes-office-new-era-cross-strait-relations (accessed August 10, 2016).

Saunders, Phillip C., and Scott L. Kastner. 2009. "Bridge over Troubled Water? Envisioning a China-Taiwan Peace Agreement.” International Security 33 (4): 87-114.

Shambaugh, David. 2003. Modernizing China's Military: Progress, Problems, and Prospects. Berkeley, CA: University of California Press.

Shlapak, David A., David T. Orletsky, Toy I. Reid, Murray Scot Tanner, and Barry Wilson. 2009. A Question of Balance: Political Context and Military Aspects of the ChinaTaiwan Dispute. Arlington, VA: RAND Corporation.

Starr, Barbara. 1995. “China's SSK Aspirations Detailed by USN Chief." Jane's Defence Weekly, March 18.

SIPRI (Stockholm International Peace Research Institute). 2016. Arms Transfer Database. 
Accessed August 27, 2016. https://www.sipri.org/databases/armstransfers.

Stokes, Mark A., and Sabrina Tsai. 2016. "The United States and Future Policy Options in the Taiwan Strait." Project 2049 Institute, February 1. http://www.project2049.net/ documents/Future_US\%20Policy\%20Options\%20in\%20the\%20Taiwan\%20Strait_ Project\%202049.pdf (accessed April 29, 2016).

Sutter, Robert. 2009. "China's Power and the Fading U.S. Goal of 'Balance' in the Taiwan Strait." Asia Policy 8: 3-9.

Swaine, Michael D. 1999. Taiwan's National Security, Defense Policy, and Weapons Procurement Processes. Santa Monica, CA: RAND.

Tan, Andrew T.H. 2014. “The Implications of Taiwan's Declining Defense." Asia-Pacific Review 21 (1): 41-62.

Thim, Michael, and Liao Yen-Fan. 2016. "Defense of Taiwan Post-2016 Elections: Legacy and New Challenges of Military Transformation." China Brief 16 (1): 6-10.

Tseng, Wei-chen, and Chen Wei-han. 2015. “Taiwanese' Identity Hits Record Level.” Taipei Times, January 26. http://www.taipeitimes.com/News/front/ archives/2015/01/26/2003610092 (accessed October 15, 2016).

USCC (U.S.-China Economic and Security Review Commission). 2010. 2010 Annual Report to Congress. November 1. http://www.uscc.gov/Annual_Reports/2010-annualreport-congress (accessed November 18, 2010).

USCC (U.S.-China Economic and Security Review Commission). 2015. 2015 Annual Report to Congress. November 17.

Wachman, Alan. 2007. Why Taiwan? Strategic Rationales for China's Territorial Integrity. Stanford: Stanford University Press.

Wang, Jianwei. 2013. "The United States and the Changing Cross-Strait Relations." In New Dynamics in Cross-Strait Relations: How Far Can the Rapprochement Go?, edited by Weixin Hu, 205-217. London: Routledge.

Wang, Vincent Wei-cheng. 2016. “Prospects for U.S.-Taiwan Relations.” Orbis: A Journal of World Affairs 60 (4): 575-591.

Womack, Brantly, and Yufan Hao., eds. 2016. Rethinking the Triangle: Washington-BeijingTaipei. Singapore: World Scientific Publishing Co.

Xin, Qiang. 2010. "Beyond Power Politics: Institution-Building and Mainland China's Taiwan Policy Transition." Journal of Contemporary China 19 (65): 525-539.

You, Ji. 2006. "China's Anti-Secession Law and the Risk of War in the Taiwan Strait." Contemporary Security Policy 27 (2): 237-257.

You, Ji. 2013. "Politics in Command of Beijing's Military Policy toward Taiwan" In New Dynamics in Cross-Strait Relations: How Far Can the Rapprochement Go?, edited by Weixin $\mathrm{Hu}, 130-150$. London: Routledge.

Zhang, Baohui. 2011. “Taiwan's New Grand Strategy.” Journal of Contemporary China 20 (69): 269-285.

Zhao, Suisheng. 2016. "Are China and Taiwan Heading Towards Conflict?" The National Interest, September 28. http://nationalinterest.org/blog/the-buzz/are-china-taiwanheading-towards-conflict-17860 (accessed October 12, 2016). 
Jingdong Yuan is an Associate Professor and Acting Director of the Centre for International Security Studies at the University of Sydney. His research focuses on Asia-Pacific security, Chinese defense and foreign policy, Sino-Indian relations, and global and regional arms control and non-proliferation issues. He is co-author of A Low-Visibility Force Multiplier: Assessing China's Cruise Missile Ambitions (2014), co-editor of Australia and China at 40 (2012), and co-author of China and India: Cooperation or Conflict? (2003). His publications have appeared in a number of refereed journals and in many edited volumes, including Asian Survey, Contemporary Security Policy, International Affairs, The Oxford Handbook of the International Relations of Asia, among others. He is currently working on a book manuscript on China's relations with South Asia. He can be reached at: jingdong.yuan@sydney. edu.au 